\title{
AN INVESTIGATION OF THE TEACHING OF BIOLOGICAL SUBJECTS IN SECONDARY SCHOOLS.
}

\author{
By Otis W. Caldwerl, \\ The University of Chicago.
}

It is frequently asserted that courses in biological subjects. indeed courses in all sciences, have not fulfilled the expectations entertained by those who were instrumental in introducing these subjects into secondary schools. As a part of an attempt to study the general situation the following investigation was undertaken.

A tripartite list of questions was sent to those who are toow engaged in teaching biological subjects in secondary schools. The first part referred to the teacher's preparation and experience, the second to the kind of course the teacher is presenting or thinks he should present, and the third to the students' opirion of various aspects of the work. Obviously important difficulties confront one who seeks such information, but it was felt that in order to have the data of value the teachers and students must be its source instead of the administrative officers of the various schools involved. It is also obvious that in this method of securing data important difficulties arise and that the lists of questions must be such as will give reasonable assurance of replies to a fair percentage of the lists sent out. It was not thought wise to attempt to cover by questions some points ripon which it is desirable to have accurate data.

A question may arise as to the trustworthiness of the data secured from the students. By reading the direction and lists it will be seen that especial effort was made to secure from the students unbiased expressions, and the nature of the replies indictates that, with possibly one or two exceptions, such were secured.

One hundred sets of the questions were sent out, each set containing one list regarding the teacher, one regarding the course, and five of the "To the Student" lists. The instructions requested that these lists for students be handed to the first five students in the class alphabetically arranged. The schools to which the lists were sent are in central, western, and eastern states and forty-nine reports were secured from teachers and pupils in thirteen states. Those schools not reporting were largely in eastern states. An attempt was made to select aver- 
age schools in large, medium sized and small towns. The size of cities and towns from which the forty-nine reports came are as follows: Population under I,000 (2); between 1,000 and 2,500 (4): between 2,500 and 5,000 (9); between 5,000 and 7,500 (4); between 7,500 and I0,000 (none); between I0,000 and 50,000 (I8); over 50,000 (I2). It must be kept in mind, however, that it is probable that the better teachers are the ones who replied and that these may often be in larger schools. Two hundred forty-three student reports were received, one hundred four of these being from boys and one hundred thirty-nine from girls.

In preparing the summary of the reports it was often necessary to reduce all the answers to a given question "to lowest terms" by selecting the chief factors in the replies. While these do not appear within quotation marks, they are faithful to the content of the answers. Answers that are taken in the exact form in which they were given are within quotation marks.

In the large amount of work requisite to a faithful summation of this data I have had the valuable assistance of $\mathrm{Mr}$. C. W. Finley, one of my students, to whom in this connection I wish to express ny gratitude.

A copy of the questions follows:

Tn the hope of securing data on the teaching of botany and zoölogy which shall be as accurate as possible, this questionaire is being sent to you and to a number of other teachers. The success of the endeavor will depend upon you and your fellow biology teachers. If you will help by taking the time and trouble to answer as accurately and fully as possible these questions, and to add on the back of the sheet any suggestions you may have that are not called for by the questions, you will contribute much. Furthermore, if you will hand the five "To the Student" blanks to the first five students in your class, beginning with the A's, collect these and return them with your reply, you will assist in giving a new angle of vision upon this problem. In case you do not have a class in botany or in zoölogy, will you please hand the blanks to the students in the last class you had in either subject. It is desired that these blanks be filled out by the students at once and without any consultation with anyone.

The results of this inquiry will be summarized and will in some form be furnished to those who request copies of the summarization. In this summarization or report, names of cities, teachers and pupils will be omitted. 
To This TEAmirr.

1. Name.

2. Address.

3. School in which employed.

4. Institution, or institutions in which you received your preparation for high school teaching.

5. Did you prepare especially to teach biology?

6. In what particular biological science (botany, zoölogy, physiology), did you do most of your work?

7. If your special preparation was in other than biological subjects, state what the subjects were.

8. What subjects are you now teaching?

9. How long have you taught botany or zoölogy in this school?

10. In any sehool?

11. In how many sebools have you taught botany or zoölogy?

12. Since beginning your teaching of these subjects, what further preparation have you made for work in biological sciences?

THE Counse.

1. Indicate whether your course is a half-year of botany and a halfyear of zoölogy, a year in botany and zoölogy, or a course in general biology.

2. In what year of the high school course are these subjects being taught?

3. What plan of course do you use? i. e., first text-book study, laboratory, field or class study; study of higher or lower forms; study of habits or of structures; as outlined in what book?

4. What proportion of your course is given to class-room work? Laboratory work? Field work?

5. Is this plan satisfactory to you?

6. If not, what would be better?

7. Are there limitations on your having as much as you wish of your work in laboratory and field? What?

8. To what extent are you at liberty to use the text-books of your own choice?

9. To what extent in orgauizing your course are college entrance requirements taken into consideration?

10. What do you think the leading purposes should be in teaching botany or zoölogy in high schools?

11. As the subjects are taught, do you think these purposes are met?

12. What is your opinion of the proposed introduction of economic, industrial, and agricultural material into the conrses in botany and zoölogy?

13. Are students interested in botany and zoölogy equally with other subjects of the curriculum?

14. What proportion of your students after going to college have: elected these subjects there?

15. What do you think are the chief difficulties in the way of a more successful study of botany and zoölogy by high-school students? 
Will the teacher kindly hand this blank to the student, asking the student to fili it out at once without consultation with anyone?

To THE STUdent.

1. Name.

2. Address.

3. School.

4. In what year of high school are you?

5. What subjects are you now studying?

6. Which do you like best?

7. How long have you studied botany or zoölogy?

8. After this course would you prefer to continue your work in botany or zoölogy by taking another course in either subject? Why?

9. What part of the zoölogy or botany work do you like best?

10. What part do you find least interesting?

11. What parts do you thiok are least valuable? Why do you think so?

12. Do you think your study of botany or zoölogy will be of any advantage to you after you are out of high school? If so, what?

13. What do you expect to do after you are out of high school?

14. Why did you study botany in the high school?

\section{THE TEACHER.}

According to the terms of the questionaire the names of teachers and their schools are not to be published, therefore question four is the first one with which we are now concerned. It is:

4. In what institution or institutions did you receive your preparation for high school teaching?

Some teachers did not report upon this point. Of the fortynine teachers but two report no work in preparation beyond the common elementary schools, and all the others report some work in normal school, college, or university. The total report averages a little less than two institutions above the high school attended by each of the forty-nine teachers. Only three master's and seven bachelor's degrees are reported, these being held by seven teachers, three of whom held two degrees, but probably in the absence of direct request for data tpon this point, several who have degrees from colleges and universities did not report that fact. More than one-fifth of all reporting have been students in normal schools. The cosmopolitan nature of the training of these forty-nine teachers is suggested by the fact that while many do not mention the particular institution which they attended, those who do name the specific institutions in all name fifty-one different institutions in which their training was received. This indicates a variety of training such as might be 
expected to result in a wide range in conception of the function of biological subjects in secondary schools.

5. Did you prepare especially to teach biological subjects?

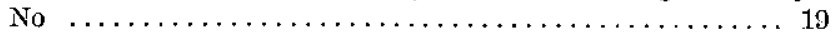

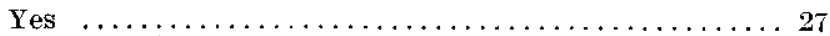

Indefinite inswers $\ldots \ldots \ldots \ldots \ldots \ldots \ldots \ldots \ldots \ldots$

6. In what particular biological sciences did you do most or your work?

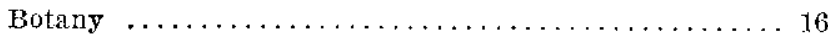

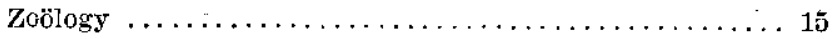

Botany and zoölogy $\ldots \ldots \ldots \ldots \ldots \ldots \ldots \ldots \ldots \ldots$

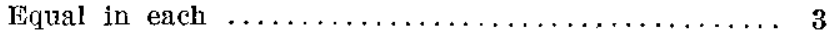

Physiology ............................ 4

Zoölogy and physiology $\ldots \ldots \ldots \ldots \ldots \ldots \ldots \ldots \ldots, 1$

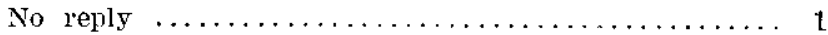

An apparent discrepancy between answers to No. 6 and No. 5 perliaps is explained by the fact that while a good many who are teaching biological sciences did not prepare for teaching this work, they nevertheless report having had some training in these subjects.

7. If your special preparation was in other than biological science, state what the subjects were.

It was especially for biological sciences $\ldots \ldots \ldots \ldots \ldots 27$

It was "general" training $\ldots \ldots \ldots \ldots \ldots \ldots \ldots \ldots$ 4

It was in chemistry $\ldots \ldots \ldots \ldots \ldots \ldots \ldots \ldots \ldots \ldots, 4$

It was in mathematies $\ldots \ldots \ldots \ldots \ldots \ldots \ldots \ldots \ldots, 4$

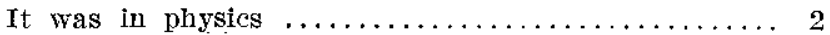

It was in physics and mathematies $\ldots \ldots \ldots \ldots \ldots \ldots, 1$

It was in geology $\ldots \ldots \ldots \ldots \ldots \ldots \ldots \ldots \ldots \ldots$

It was in geology and history $\ldots \ldots \ldots \ldots \ldots \ldots \ldots \ldots$

It was in languages $\ldots \ldots \ldots \ldots \ldots \ldots \ldots \ldots \ldots$

It was in English and history $\ldots \ldots \ldots \ldots \ldots \ldots \ldots, 1$

It was in English and drawing $\ldots \ldots \ldots \ldots \ldots \ldots \ldots 1$

It was in Latin ........................ 1

Not answering this point $\ldots \ldots \ldots \ldots \ldots \ldots \ldots \ldots \ldots$

3. What subjects are you now teaching?

Teaching botany alone $\ldots \ldots \ldots \ldots \ldots \ldots \ldots \ldots, 3$

Botany aud zoölogy .................... 6

Botany, zoölogy, and one other subject $\ldots \ldots \ldots \ldots \ldots, 9$

Botany, zoölogy, and two other subjects ......... 5

Botany, zoollogy, and three other subjects ......... 1

Botany and one other not counting the cases above where botany, and another biological subject are

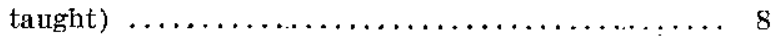

Botany and three others (not biological) ......... 3

Zoölogy and one other (not biological) $\ldots \ldots \ldots \ldots \ldots, 1$

Zoölogy and two others (not biological) .......... 2 
Zoölogy and three others (not biological) $\ldots \ldots \ldots \ldots, 1$

Zoölogy and four others (not biological) .......... 1

Not now teaching any biological subject .......... 1

The detailed data show that with these forty-nine teachers thirty-one different combinations of the subjects taught are presented. Practically every subject within the wide range of high school curricula is in some case associated with botany in the hands of one teacher, or perhaps it should be said that botany is found in the hands of the teacher of practically every subject in high school curricula.

The number of strbjects taught by these teachers is suggestive:

Those teaching but one subject $\ldots \ldots \ldots \ldots \ldots \ldots \ldots, 3$

Those teaching two subjects $\ldots \ldots \ldots \ldots \ldots \ldots \ldots \ldots$ 15

Those teaching three subjects $\ldots \ldots \ldots \ldots \ldots \ldots \ldots, 19$

Those teaching four subjects $\ldots \ldots \ldots \ldots \ldots \ldots \ldots \ldots, 9$

Those teaching five subjects $\ldots \ldots \ldots \ldots \ldots \ldots \ldots \ldots, 2$

Combination not reported $\ldots \ldots \ldots \ldots \ldots \ldots \ldots \ldots, 1$

9. How long have you taught botany or zoölogy?

Those in first year of teaching of botany ......... 13

The average number of years of teaching botany in one school (excluding the thirteen who are in their first year in their present school) $\ldots \ldots \ldots \ldots \ldots \ldots \ldots, 7$ years.

Longest period of teaching botany in one high school 18 years.

Io. How long have you taught botany or zoölogy in all high schools?

Average (excluding those who are in their first year of

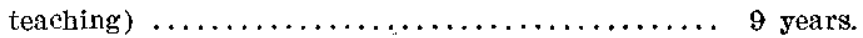

Longest period of teaching botany in all high schools.. 21 years.

II. In how many schools have you taught botany or zoölogy?

Average (excluding those who are in their first

year of teaching botany or zoölogy).... 2\% schools.

Largest number of high schools in which one

teachei has taught botany or zoölogy...6 6 schools.

The data also shows that the ten who have taught botany longest in the high schools have averaged fifteen and one-fifth years each and that these years of teaching have been in an average of two and two-fifths schools, a number of schools slightly below the average for all teachers (excluding those who are in their first years of teaching). It is also further interesting to note that these ten have prepared themselves specially for the teaching of botany.

II. Since beginning your teaching what further preparation have you made for work in biological sciences?

Ideas as to what may constitute "further preparation" are so diverse that rather full quotation must be made from the reports : 
No further preparation $\ldots \ldots \ldots \ldots \ldots \ldots \ldots \ldots \ldots, 4$

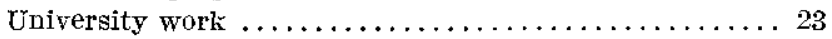

Read text-books and periodicals $\ldots \ldots \ldots \ldots \ldots \ldots \ldots 12$

Private work $\ldots \ldots \ldots \ldots \ldots \ldots \ldots \ldots \ldots \ldots \ldots$

Attended biological meetings $\ldots \ldots \ldots \ldots \ldots \ldots \ldots \ldots \ldots, 4$

Collected material $\ldots \ldots \ldots \ldots \ldots \ldots \ldots \ldots \ldots \ldots \ldots$

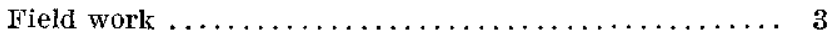

Research ............................ 3

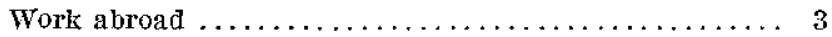

Special work in slide making $\ldots \ldots \ldots \ldots \ldots \ldots \ldots \ldots, 1$

Tried to keep up with the times $\ldots \ldots \ldots \ldots \ldots \ldots \ldots \ldots, 1$

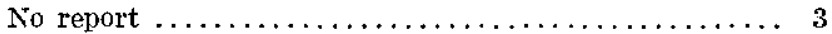

It will be noted that several teachers have cited two or more kinds of work thus making an aggregate in excess of the fortynine teachers reporting.

Obviously it would be of interest to make a study of relations that may exist between the teacher's report upon his own training and experience and his report upon what he considers shall be the nature of his course, but such an individual study of reports cannot now be presented.

\section{T'He Course.}

I. Indicate whether your course is a half year of botany and a half year of zoölogy, a year in botany and a year in zoology or a course in general biology.

The summarization of replies follows:

One year of botany, no separate course in zoölogy, biology, or physiology ................. 14

One-half-year botany and one-half-year zoölogy $\ldots \ldots, 9$

General biology, no separate course in zoölogy, botany, or physiology $\ldots \ldots \ldots \ldots \ldots \ldots \ldots \ldots \ldots \ldots \ldots \ldots$

One year of zoölogy, no separate course in botany, biology. or physiology $\ldots \ldots \ldots \ldots \ldots \ldots \ldots \ldots \ldots$

One year biology, one year botany, and one year zoölogy 1

One year botany and one year zoölogy .......... 5

One-half year botany, one-half year zoölogy, and onehalf year physiology $\ldots \ldots \ldots \ldots \ldots \ldots \ldots \ldots, 1$

One-half year botany and one year zoölogy ........ 1

One year botany and one-half year zoölogy ........ 1

one-half year botany alone $\ldots \ldots \ldots \ldots \ldots \ldots \ldots \ldots, 2$

One-half year botany and one-half year physiology ... 1

One year botany and one year physiology ......... 1

Two years botany and one-half year zoölogy ...... 1

One year "nearly all zoölogy but a little botany" ..... 1

One-half year botany and one-half year zoölogy plus a

full year of elective in each $\ldots \ldots \ldots \ldots \ldots \ldots \ldots, 1$

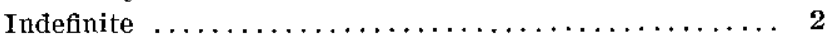


It is evident that the above answers show about all the combinations that are possible. There seems to be no danger as yet: of too great rigidity in the kinds of courses given. It would. be difficult to account for these wide variations upon the basis of adjustment to peculiar local conditions. When we consider, however, that these forty-nine cases present no less than fifteen different combinations it would seem important to find the causes. of such variation.

2. In what year of the high school are these subjects being. taught?

All the biological work confined to first year $\ldots \ldots \ldots 7$

All the biological work confined to second year ...... 21

All the biological work confined to third year ...... 2

All the biological work confined to fourth year ..... 2

Botany first year and zoölogy second year ........ 4

Botany first year and zoölogy third year ......... 1

Botany first year and physiology second year ...... 1

Botany second year and zoölogy first year .......... 1

Botany second year and zoölogy third year ........ 1

Botany first and second years $\ldots \ldots \ldots \ldots \ldots \ldots \ldots$. 1

Botany second and third years $\ldots \ldots \ldots \ldots \ldots \ldots \ldots, 2$

Botany fourth year and zoölogy first year ......... 1

Physiology first year $\ldots \ldots \ldots \ldots \ldots \ldots \ldots \ldots \ldots, 1$

First and second year classes combined, physiology and physiography being given in alternate years ...... 3

No answer $\ldots \ldots \ldots \ldots \ldots \ldots \ldots \ldots \ldots \ldots \ldots \ldots, \ldots \ldots$

3. What plan of course do you use, i. e., first text-book study, laboratory, field or class study, study of higher or lower forms, study of habits or structures; as outlined in what text-book?

The replies upon this topic are necessarily so varied that it is difficult to reduce them to a satisfactory form of presentation, the fault being due probably to the lack of organization of the points involved in the topic. Of the forty-nine replies eighteen state definitely that they follow the work as laid out in text-book and laboratory manual, while eight state that they first take up laboratory work based upon their own outlines, then follow with text-book work; and then have some field work. A small number express a preference for first studying by use of text-book, then having laboratory work upon types discussed in text-book study. The majority present structures first, some following this by a study of physiology and ecology, these being represented by some who say "structure most important, then functions and adaptations." Nearly all begin their work by use of "higher forms" and most follow this by some study of "lower 
forms," though some onit the latter from the course. Some study homologies of structures and evolution of higher forms, while some find these things not understandable by high school students.

The previously mentioned wide variation is further emphasized when we note that in botany, zoology and general biology (exclusive of physiology) sixteen different kinds of text-books are used.

4. What proportion of your course is given to class-room work, to laboratory work, and to field work?

Most time given to class-room work ........... 15

Most time given to laboratory work ............ 25

Time evenly divided between class and laboratory work 5 Most time given to field work $\ldots \ldots \ldots \ldots \ldots \ldots \ldots \ldots 1$

Indefinite replies $\ldots \ldots \ldots \ldots \ldots \ldots \ldots \ldots \ldots \ldots, \ldots \ldots$

5. Is the plan as you report it in the preceding section satisfactory to you?

The above plan is not satisfactory $\ldots \ldots \ldots \ldots \ldots \ldots 31$

The above plan is satisfactory $\ldots \ldots \ldots \ldots \ldots \ldots, 16$

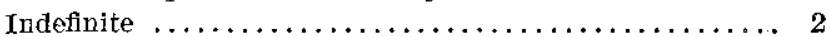

6. What would be better than the plan you use?

More field work $\ldots \ldots \ldots \ldots \ldots \ldots \ldots \ldots \ldots \ldots \ldots$

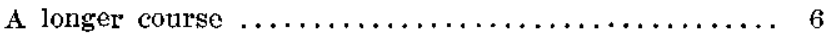

More laboratory work $\ldots \ldots \ldots \ldots \ldots \ldots \ldots \ldots \ldots, 2$

Stmaller ciasses $\ldots \ldots \ldots \ldots \ldots \ldots \ldots \ldots \ldots \ldots \ldots \ldots, 2$

A combination of class, field, and laboratory work ... 2

A greeuhouse or a school garden to increase facilities

for experimentation $\ldots \ldots \ldots \ldots \ldots \ldots \ldots \ldots \ldots, 2$

More apparatus ....................... 1

Not replying to this point $\ldots \ldots \ldots \ldots \ldots \ldots \ldots \ldots \ldots$

7. What limitations are there upon your having as much as you wish of your time in the laboratory or field?

There are no limitations $\ldots \ldots \ldots \ldots \ldots \ldots \ldots \ldots, 8$

Limited by crowded program either of teacher, or student, or both $\ldots \ldots \ldots \ldots \ldots \ldots \ldots \ldots \ldots \ldots 29$

Lack of adequate laboratory apparatus ............ 7

Lack of adequate room ........................ 4

Distance from suitable field region $\ldots \ldots \ldots \ldots \ldots \ldots, 4$

Classes too large $\ldots \ldots \ldots \ldots \ldots \ldots \ldots \ldots \ldots \ldots, 2$

Expense of field trips $\ldots \ldots \ldots \ldots \ldots \ldots \ldots \ldots \ldots, 1$

After-school work of pupils $\ldots \ldots \ldots \ldots \ldots \ldots \ldots \ldots, 1$

No interpretable answer $\ldots \ldots \ldots \ldots \ldots \ldots \ldots \ldots, 4$

Several teachers reported two or more limiting factors. The most serious difficulty with the amount of laboratory and field work that teachers would like to do is reported as being the difficulty that is had in securing time for these things. This is 
due to the interference thus made with other school and home duties both of the teachers and pupils.

8. To what extent are you free to use the text-book of your choice?

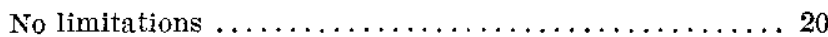

No voice in choosing $\ldots \ldots \ldots \ldots \ldots \ldots \ldots \ldots \ldots$ is

May choose, subject to approval by school board ..... 10

Indefinite answers or no answers $\ldots \ldots \ldots \ldots \ldots \ldots 6$

9. To what extent in organizing your courses are college entrance requirements taken into consideration?

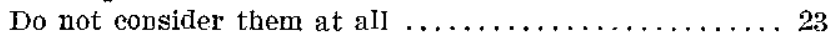

Plan course to meet college requirements .......... 19

Must meet requirements in state course of study .... 3

No answer $\ldots \ldots \ldots \ldots \ldots \ldots \ldots \ldots \ldots \ldots \ldots \ldots \ldots \ldots$

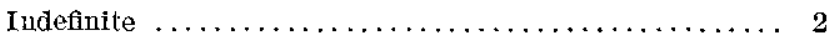

It is not possible adequately to quote many of the answers to this question but they range all the way from those who said, "This is all any high school is for," and "We are a part of our state school system and if we don't follow the dictates of the state university we'll be cut off their accredited list and will get no financial or educational support," to those who say that "too much stress is laid upon meeting entrance requirements in science," and "the colleges should accept what we think is best for the students."

Io. What do you think the leading purposes should be in teaching botany or zoölogy in the high school?

Emphasized scientific training ............... 17

Emphasized development of love and knowledge of

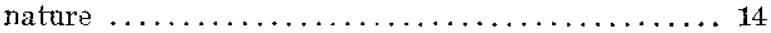

Emphasized preparation for more efficient living ...... 9

Emphasized ecological knowledge of plants or animals $\mathbf{5}$

Emphasized economic relation of plants or animals .... 4

Emphasized preparation for continued work ........ 2

Emphasized knowledge of evolution $\ldots \ldots \ldots \ldots \ldots \ldots, \mathbf{2}$

Not answering this question $\ldots \ldots \ldots \ldots \ldots \ldots \ldots \ldots$

This summarization of the purposes given by these forty-nine teachers by no means does justice to their replies, since many of them speak at length and with clearness concerning the purposes they have in mind for the work. The following quotation of phrases indicates more fully the nature of the replies: "Love for nature, pleasure and profit," "structure and habits of living things and their relation to men," "accurate knowledge and love for science," "acquaintance with environment, culture and self-preservation," "knowledge of form, struc- 
ture and ecology and classification," "acquaintance with nature and training in scientific thought," "broadening of outlook and practical application," "trend of scientific thought," "scientific observation and practical information," "acquaintance and sympathetic observation and a deeper hold on life," "scientific training," "broad, general and practical information," "to develop independ. ent thinking;" "to introduce to a field for future browsing," "to teach organization of systems of plants and animals," "accuracy, evolution and practical work," "economic value of plants both helpful and harmful."

II. As these subjects are taught do you think these purposes are met?

To make the data on this point most meaningful it would be well to associate each teacher's reply with the purpose for which he thinks the courses are given. Such would require more space than can now be used. However, of the forty-nine teachers:

The number believing the purposes they state are met,

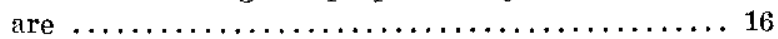

The number believing the purposes they state are not met, are $\ldots \ldots \ldots \ldots \ldots \ldots \ldots \ldots \ldots \ldots \ldots \ldots \ldots$

The number saying, "Fairly well," or similar expressions, are $\ldots \ldots \ldots \ldots \ldots \ldots \ldots \ldots \ldots \ldots \ldots, 19$

The number not replying are $\ldots \ldots \ldots \ldots \ldots \ldots \ldots \ldots . \quad 3$

12. What is your opinion of the proposed introduction of economic, industrial and agricultural materials into the courses in botany and zoölogy?

Those approving are $\ldots \ldots \ldots \ldots \ldots \ldots \ldots \ldots \ldots, 20$

Those disapproving are $\ldots \ldots \ldots \ldots \ldots \ldots \ldots \ldots \ldots, 5$

Those partially approving but strongly' expressing doubts

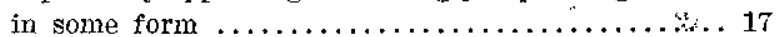

Indefinite or not answering $\ldots \ldots \ldots \ldots \ldots \ldots \ldots, 7$

Many reasons are cited as: "Not time for this in the course," "favor it, pupils interester in it, appeals to practical and awakens appreciation of course," "only a small amount should be undertaken," "needs of locality should decide," "useful knowledge sustains interest," "adds interest and practical value and does not hinder scientific interest," "danger of crowding in too much and of forgetting our students are young," "the fundamentals and more important things already crowd a year's course," "I disapprove it," "excellent for country high schools," "include it unless a separate cotrse for agriculture be given."

I3. Are students interested in botany and zoölogy equally with other subjects? 


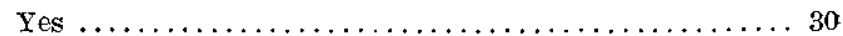

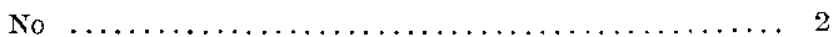

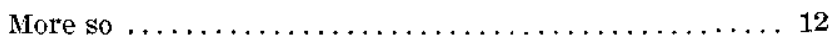

Don't know $\ldots \ldots \ldots \ldots \ldots \ldots \ldots \ldots \ldots \ldots \ldots \ldots \ldots, 2$

"Yes, when not subjected to outside influences" ...... 1

Not answering $\ldots \ldots \ldots \ldots \ldots \ldots \ldots \ldots \ldots \ldots \ldots \ldots \ldots$

In examining these answers it must be kept in mind that irr many schools the biological subjects are entirely elective andi this fact may influence the relative popularity of the work with those who take it. If only those take these subjects who have a strong natural interest in them they will probably think better of the courses than would the average student if all were required to take these subjects.

I4. What proportion of your students after going to college elect botany or zoölogy?

To this question nearly all the teachers replied that they do not know what their students have elected in college. Those giving data are not clear as to its accuracy and it will not be quoted.

I5. What do you think are the chief difficulties in the way of a more successful study of botany and zoölogy by high school students?

Lack of proficient teachers $\ldots \ldots \ldots \ldots \ldots \ldots \ldots \ldots \ldots 12$

Lack of more time for work $\ldots \ldots \ldots \ldots \ldots \ldots \ldots \ldots, 12$

Lack of apparatus ....................... 12

Lack of adequate field work $\ldots \ldots \ldots \ldots \ldots \ldots \ldots \ldots, 10$

Iack of material ..................... 7

The position and crowded nature of science in the

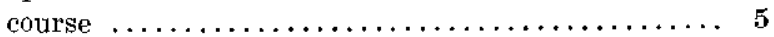

Large classes $\ldots \ldots \ldots \ldots \ldots \ldots \ldots \ldots \ldots \ldots \ldots \ldots \ldots, 4$

Too little emphasis on economic aspects .......... 4

Not adequate laboratory work $\ldots \ldots \ldots \ldots \ldots \ldots \ldots \ldots, 3$

Poor text books $. \ldots \ldots \ldots \ldots \ldots \ldots \ldots \ldots \ldots \ldots, 3$

Lack of good laboratory manuals .............. 2

Ignorance of parents regarding use cf botany and zo ogy 2

"Subjects taught as 'makeshifts' by teachers of other subjects" ...................... 2

"Teachers too many subjects to teach" ............ 2

"Abhorrence of parents against evolution and descent". 1

"Let pupils do more work and teachers less talking" .. 1

"Too frequent change of teachers" ............. 1

"Pupils have too many outside interests" ......... 1

"Making work too mature" .................. 1

The Student.

The total number of students replying to their lists is two hundred forty-three. Of these one hundred four are boys and 
one hundred thirty-nine are girls. The names of nearly all of them begin with letters within the first part of the alphabet, thus indicating that teachers followed directions in handing out the blanks. Furthermore, barring the possibility of as single set of student papers the indications are that perfectly fair and dependable methods were used by teachers in securing the kinds. of reports that were desired.

The question of the year of the high school in which the biological subjects came was amply covered under The Course.

It must be kept in mind that although two hundred fortythree students reported, not all were having a biological science at the time the report was made. Some reported upon courses previously completed.

2. Number studying botany at time of report......... 129

(Of these fifty-three were boys, this being fifty-five per cent of the total number of girls. This indicates that it is not botany, but high schools that seem to be most largely for girls.)

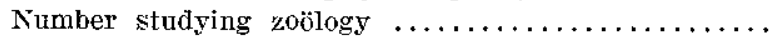
(Of these twenty-seven were boys, twenty-six per cent of all boys, and thirty-two were girls, twentyfour per cent of all the girls.)

Number studying general biology ............ 22 (Of these twelve were boys and ten were girls.)

English ........................... 215

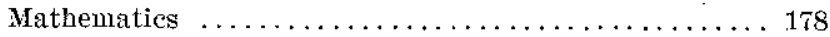

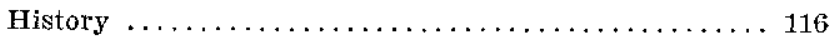

Latin ............................ 107

German $\ldots \ldots \ldots \ldots \ldots \ldots \ldots \ldots \ldots \ldots \ldots \ldots \ldots \ldots$

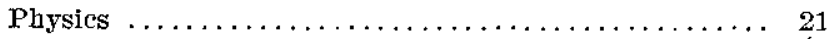

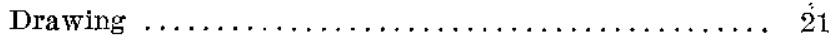

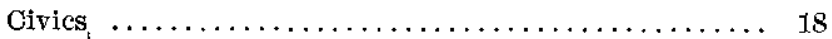

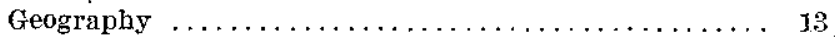

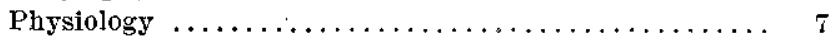

General Elementary Science $\ldots \ldots \ldots \ldots \ldots \ldots \ldots \ldots$

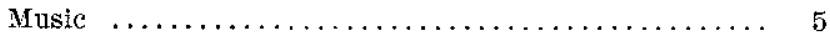

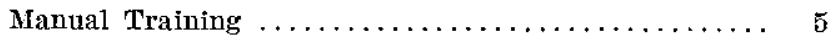

Domestic Science ....................... 3

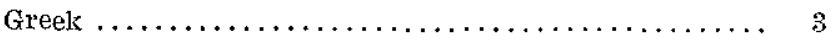

Other subjects (including French) $\ldots \ldots \ldots \ldots \ldots \ldots 28$

6. Which subjects do you like best?

ZoöIogy with 59 students has 20 or $34 \%$ of those who take it preferring it to all other subjects.

Botany with 129 students has 41 or $31 \%$ preferring it. Mathematics with 178 students has 42 or $24 \%$ preferring it. German... with 69 students has 22 or $31 \%$ preferring it. History.. . with 116 students has 27 or $23 \%$ preferring it. 
Latin.... with 107 students has 14 or $13 \%$ preferring it. English.. . with 215 students has 27 or $12 \%$ preferring it. Chemistry with 15 students has 11 or $73 \%$ preferring it.

In all there are sixty-nine preferences of biological subjects (botany, zoölogy or general biology) or thirty-two per cent of the total number of students taking these subjects. This may be misleading owing to a possible tendency on the part of pupils to give a more favorable report to the subjects used as the basis of the questions.

7. How long have you studied botany or zoölogy?

The average length of course of all these students at the time of making the report was a little more than four months.

8. After this year would you like to take a further course in botany or zoölogy?

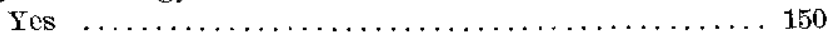

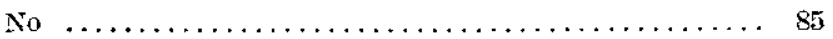

Noncommittal $\ldots \ldots \ldots \ldots \ldots \ldots \ldots \ldots \ldots \ldots, 8$

Why?

r. Those not desiring a further course:

of no use to me $\ldots \ldots \ldots \ldots \ldots \ldots \ldots \ldots \ldots \ldots \ldots, 19$

Not interesting-can't get interested in it, etc. .... 17

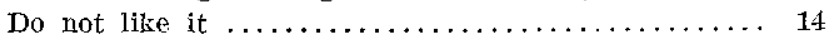

Do not intend to specialize in it .............. 4

Other answers of similar nature $\ldots \ldots \ldots \ldots \ldots \ldots .31$

2. Those desiring to take further courses:

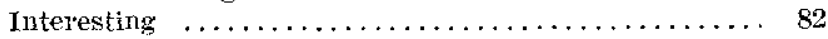

Think it will be useful $\ldots \ldots \ldots \ldots \ldots \ldots \ldots \ldots \ldots \ldots, 41$

Want to know more about it $\ldots \ldots \ldots \ldots \ldots \ldots \ldots \ldots$

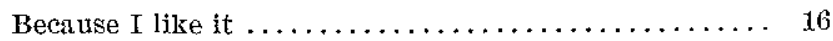

Love nature and want to know more about it $\ldots \ldots \ldots$. 7

It will help in study of medicine $\ldots \ldots \ldots \ldots \ldots \ldots \ldots, 2$

"Xes, if there is any text-book that talses it up in a more interesting manner" . ............... 1

9. What part of the work do you find least interesting?

In these replies practically all aspects of the course are cited by some one or more students as least interesting. The eight leading "uninteresting" features are given:

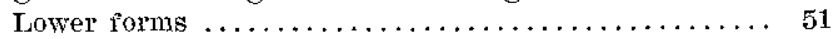

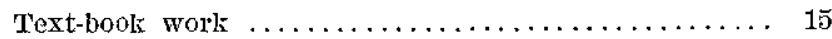

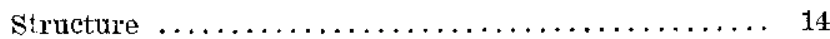

Classification and analysis $\ldots \ldots \ldots \ldots \ldots \ldots \ldots$. 15

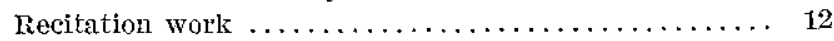

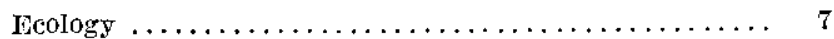

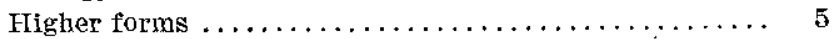

Plant societies $\ldots \ldots \ldots \ldots \ldots \ldots \ldots \ldots \ldots \ldots \ldots \ldots \ldots$ 
IO. What parts of the work do you think are least valuable to you?

These answers were of such a nature that they could be grouped about factors that were essentially the same though of course not stated in the same way by different students. The eight factors receiving most frequent mention are given:

No part is least valuable to me $\ldots \ldots \ldots \ldots \ldots \ldots 21$

Lower forms are least valuable $\ldots \ldots \ldots \ldots \ldots \ldots \ldots 41$

Scientific names ........................ 14

Structural studies, including morpbology ........ 14

Analysis and classification $\ldots \ldots \ldots \ldots \ldots \ldots \ldots \ldots, 11$

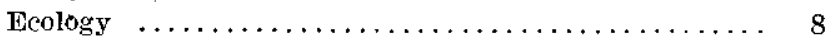

Physiology ............................. 6

Microseopic work $\ldots \ldots \ldots \ldots \ldots \ldots \ldots \ldots \ldots \ldots \ldots$

The reasons assigned for students' opinions of lack of relative values of the aspects of the course which they think of least value are many, but most interesting. The leading ones are:

of no use to me, no benefit, not worth while ....... 63

These details are soon forgotten and require too nuch time for what is gotten from them ......... 15

Not interesting and never seen in practical life ..... 14

Does not help me in what I am going to do ...... 8

Most interesting aspects of the subject should receive more attention $\ldots \ldots \ldots \ldots \ldots \ldots \ldots \ldots \ldots \ldots \ldots$

Too dificult to learn $\ldots \ldots \ldots \ldots \ldots \ldots \ldots \ldots \ldots \ldots$

Some quoted replies may be of interest in giving fully the students' point of view, the first part of the quotations being the student's "least valuable" part of the work and the latter part his reason therefor. "Detailed structures...... merely name finding." "Detailed structures...... I don't care if there is protoplasm in plants." "Laboratory...... too much cutting up to do." "Microscopic work..... of no use," an answer which in some form is very common. "Text-book work...... cannot understand the book." "Text-book. .....field work far better." "Text work without laboratory..... hard to remember without seeing." "Plant physiology...... course not long enough to pay." "Ecology...... a person generally knows what he finds is usually found in different regions." "Field work...... can be learned from a book." "Drawing...... time wasted."

II. What parts of the work do you think are most valuable to you?

Through error in preparing the sheets this question was omitted from most of the sets, hence a small proportion of reports cover this point. In a way a check is secured because the 
fact that query ten, the opposite of eleven, was in all the sets. It is interesting to note, however, (I) that some students see no particular value in the work, and (2) that most of them select definitely a particular aspect and give a good reason for so doing. The opinions on this point are widely and generally distributed. Some of the answers follow: "Higher forms...... we can see the higher forms." "Observation...... you can see and know for yourself." "Laboratory...... you can see and know for yourself." "Memorizing names..... develops memory." "Learning parts of animals...... can understand general classes of animals." "Study of mammals...... most like people." "Leaves and flowers...... because I understand them." "Morphology...... teaches underlying principles." "Leaves, roots, stems and seeds..... they include all the plant." "Textbook work......the writings of important men." "Grafting of plants," "Forestry," "Disease producing plants and animals," "Plant breeding," "Stock breeding," "Economic aspects of plants and animals." The last group of quotations are samples of the kinds of replies that predominate throughout the reports, nearly all students making such statements following with a statement that such things are of more interest and of some use to them.

I2. Do yout think your botany and zoölogy will be of any use to you after you are out of high school?

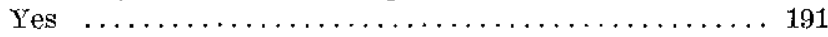

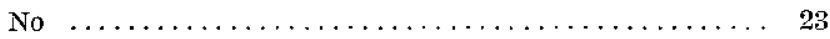

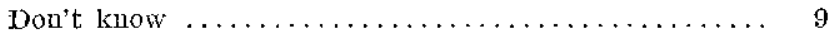

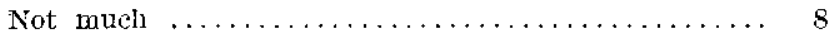

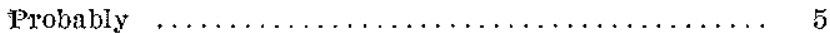

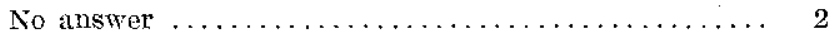

13. If of any use, what do you think that is?

Pleasure and appreciation of nature ........... 57

Knowledge of mature, ability to read better, etc. .... 56

Help in future work $\ldots \ldots \ldots \ldots \ldots \ldots \ldots \ldots \ldots \ldots, 42$

Will help in raising plants $\ldots \ldots \ldots \ldots \ldots \ldots \ldots \ldots \ldots, 7$

Help to prevent disease $\ldots \ldots \ldots \ldots \ldots \ldots \ldots \ldots \ldots, 6$

Will help to get along better $\ldots \ldots \ldots \ldots \ldots \ldots \ldots \ldots, \mathbf{5}$

Aids in getting more knowledge $\ldots \ldots \ldots \ldots \ldots \ldots \ldots .3$

14. What do you intend doing when you are out of high school?

Take a college course $\ldots \ldots \ldots \ldots \ldots \ldots \ldots \ldots \ldots, 80$

Have not decided $\ldots \ldots \ldots \ldots \ldots \ldots \ldots \ldots \ldots \ldots \ldots, 40$

Teach school $\ldots \ldots \ldots \ldots \ldots \ldots \ldots \ldots \ldots \ldots \ldots \ldots, \quad 35$

Take a course in music $\ldots \ldots \ldots \ldots \ldots \ldots \ldots \ldots . \ldots \ldots \ldots \ldots$

Take an engineering course $\ldots \ldots \ldots \ldots \ldots \ldots \ldots \ldots, 11$ 
Take a business course $\ldots \ldots \ldots \ldots \ldots \ldots \ldots \ldots \ldots, 10$

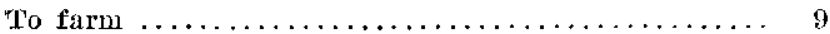

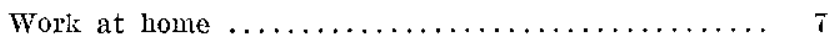

To be a trained nurse $\ldots \ldots \ldots \ldots \ldots \ldots \ldots \ldots \ldots \ldots$

Take a medical course $\ldots \ldots \ldots \ldots \ldots \ldots \ldots \ldots \ldots \ldots$

Take a domestic science course $\ldots \ldots \ldots \ldots \ldots \ldots \ldots, \mathbf{5}$

Be a stenographer $\ldots \ldots \ldots \ldots \ldots \ldots \ldots \ldots \ldots \ldots \ldots \ldots$

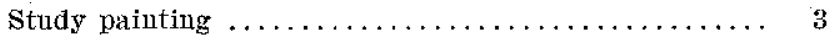

Take an agricultural conrse $\ldots \ldots \ldots \ldots \ldots \ldots \ldots, \mathbf{2}$

Study elocution $\ldots \ldots \ldots \ldots \ldots \ldots \ldots \ldots \ldots \ldots \ldots \ldots$

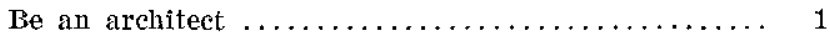

Take a naval course $\ldots \ldots \ldots \ldots \ldots \ldots \ldots \ldots \ldots \ldots$

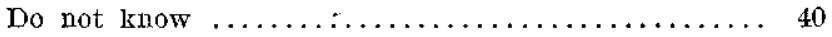

15. Why did you study botany in the high school?

This question selects one of the biological courses in order to make more definite the replies upon a single aspect of the problem.

"It came in the course," or "it was required," or "to get the credit," or "to use it in getting into college," or "one science is required" ......... 47

Wanted to learn about plants ............... 25

The subject was interesting $\ldots \ldots \ldots \ldots \ldots \ldots \ldots, 18$

I took it rather than another subject $\ldots \ldots \ldots \ldots \ldots \ldots, 12$

I thought it would be useful $\ldots \ldots \ldots \ldots \ldots \ldots \ldots, 12$

I thought $I$ would like it $\ldots \ldots \ldots \ldots \ldots \ldots \ldots \ldots, 10$

I always liked nature, or science, or plants ...... 9

"Because I like flowers" .................. 4

I heard others praising the course $\ldots \ldots \ldots \ldots \ldots \ldots, 3$

"Because my friend took it" ................. 1

"Because my teacher advised me" .............. 1

"Because I thought it would be easier" ......... 1

"It was necessary if I became a teacher" ........ 1

"It is something everyone should know".......... 1

"To broaden my education" ................. 1

"I always liked experimental work" $\ldots \ldots \ldots \ldots \ldots \ldots 1$

"At first because it came in my course, then because I

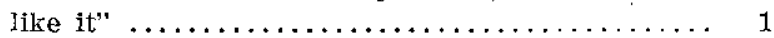

"I needed the credits" (included above) ............

"Because my parents wanted me to" .......... 1

It is obvious to all who have had experience in secondary schools that many inferences are possible from some of these data. In this connection no attempt has been made to present the full meaning of the facts as herre shown. These things are presented in the belief that it will help us to know these facts regarding the problem of biological education, and further inference regarding these facts may prove of interest at a later sate. 